\title{
CONSIDERAÇÕES HISTÓRICO- ARQUEOLÓGICAS COMO ELEMENTOS PARA UMA REAVALIAÇÃO DE MAX WEBER
}

\author{
Historical-Archaeological considerations as elements \\ for a reassessment of Max Weber \\ Andréa Bernardes de Tassis Ribeiro *
}

\begin{abstract}
RESUMO
De acordo com Max Weber, a ética judaica foi diretamente influenciada pelo desenvolvimento da Torá sacerdotal, na qual os costumes tradicionais de ritual produziram elementos que deram ao judaísmo seu status de pária no mundo. Embora a posição de Weber encontre respaldo na documentação histórica e arqueológica da pesquisa mais moderna, a afirmação do sociólogo de que a posição de povo forasteiro teve por fundamento a impenetrabilidade ritual, ainda na época deuteronômica, é refutada por recentes pesquisas segundo as quais, somente no exílio e pós-exílio, as leis de caráter ritualista e preservacionista foram melhor observadas.
\end{abstract}

Palavras-chave: Max Weber; povo pária; Torá; Iahweh; Israel

\begin{abstract}
According to Max Weber, the Jewish ethics was directly influenced by the development of the Torah, in which traditional customs of ritual produced elements that gave his pariah status of Judaism in the world. Although the position of Weber find support on archaeological and historical documentation of modern research, the sociologist's assertion that the position of people from out of town had based the impenetrability ritual, even at the time of Deuteronomy, is refuted by recent research that only in exile and after exile, the segregationist and ritualistic laws were better observed.
\end{abstract}

Keywords: Max Weber; pariah people; Torah; Iahweh; Israel

\footnotetext{
* Licenciada em História pela Universidade Federal de Ouro Preto em 2009, recebeu, em 2014, o tírulo de Mestra em Ciência da Religião pela Universidade Federal de Juiz de Fora defendendo a dissertação de título História e religião na análise weberiana sobre o "povo de Israel" como um "povo pária".
} 
Para Weber, é possível entender o povo judeu como um povo segregado a partir, principalmente, de questões religiosas ou rituais que podem ser localizadas em um período anterior ao exílio babilônico, devido à moralidade dual, desenvolvida pela comunidade que agia de uma forma com seus membros e de outra com os estrangeiros. Logo no início de Ensayos sobre sociologia de la religión, III, o autor define os judeus como povo pária:

Um povo forasteiro, segregado ritualmente, de maneira formal ou de fato, de seu ambiente social. Tal condição pode deduzir todas as características essenciais do seu comportamento contra o ambiente, especialmente sua voluntária existência de gueto, muito anterior ao tempo do seu confinamento forçado e a modalidade do dualismo de moral de dentro e de moral de fora (WEBER, 198788 , p. 16/17).

Segundo Weber, essa dualidade se deve, principalmente, no período pós-exílico, à Torá sacerdotal, sendo esta determinante na produção dos elementos que transformaram os judeus em um povo segregado. Para o sociólogo, embora originariamente não existisse nenhum tipo de segregação ritual entre naturais e estrangeiros em Israel, mesmo antes do exílio babilônico, a comunidade começou a se desenvolver em direção a uma comunidade confessional, ritualmente segregada (WEBER, 1987-88, p.361/362).

No período do exílio babilônico, entretanto, e principalmente, no período pós-exílico, é possível identificar o estabelecimento de uma legislação ritual levada a cabo de forma que os judeus tornaramse um povo pária, segregado, com ponto central de culto em Jerusalém e comunidades filiais espalhadas pelo mundo. Weber destaca que, do ponto de vista social, principalmente os camponeses tinham dificuldades em cumprir muitas das determinações rituais de forma inteiramente corretas, 
Não só porque o Šabāth, o ano sabático e prescrições alimentares eram difíceis de cumprir nas condições de vida rural, mas, acima de tudo, porque para viver uma vida adequada o progressivo desenvolvimento dos preceitos que regiam a conduta foi essencial para instruirse no ritual (WEBER, 1987-88, p. 387/388).

Dessa forma, pode-se resumir a análise de Weber em três pontos principais: 1) a condição de povo segregado inicia-se antes do período do exílio babilônico; 2) a segregação deriva-se de leis religiosas de caráter ritualístico; 3) identificam-se os principais elementos da segregação judaica na Torá sacerdotal. Embora os dois últimos pontos se expressem no mesmo sentido deste artigo, o primeiro não se verifica de acordo com a análise feita.

Ao pesquisar, portanto, a origem das formas de segregação experimentadas pelo "povo de Israel", percebe-se grande divergência entre os estudiosos, de forma que, enquanto alguns localizam a fonte da segregação nas escrituras, outros a localizam nos acontecimentos históricos que envolvem esse povo e que são mais amplos que a experiência de pertencimento étnico, religioso ou cultural.

Embora a procedência, ou origem dos indivíduos, seja um fator de pertencimento a um grupo, para Weber, os costumes comuns, geralmente advindos de fontes diversas, "originam-se em alto grau na adaptação às condições naturais externas e na imitação dentro do círculo da vizinhança" (WEBER, 1991, p. 274). Ou seja, para o sociólogo, a chamada "consciência tribal", ou o reconhecimento de indivíduos pertencentes a um mesmo grupo ou povo, está condicionada principalmente aos destinos políticos e costumes comuns. Dessa forma, mesmo sabendo que o "povo de Israel" originou-se por meio da integração de diversos indivíduos e da adaptação dos mais diferentes costumes aos seus próprios preceitos religiosos, qualquer um que quisesse ser aceito como pertencente ao grupo deveria aceitar a religião de Iahweh e com ela a forma de vida desse povo.

Essa forma, por sua vez, encontrava-se determinada pela lei da aliança que, para Weber, constitui a fonte da autossegregação desse povo perante seus vizinhos e o mundo circundante, já que, 
segundo as próprias narrativas hebraicas, o "povo de Israel" autodenominava-se "povo escolhido", eleito entre os demais para ser o "povo de Iahweh", ou seja, o povo escolhido entre todas as nações para ser o "povo de Deus".

Utilizando a expressão "voluntária existência de gueto", Sell, em sua recente análise sobre Weber, considera que o sociólogo alemão compreende o judaísmo antigo como um povo forasteiro, ritualmente segregado dentro do ambiente social em que vive. Weber, entretanto, acreditava que essa voluntária segregação tinha origem, antes do exílio babilônico, no dualismo entre a moral interna e a moral externa, como explicitado. A documentação arqueológica contesta esse dado, já que, mesmo com a tentativa de centralização do culto em Jerusalém e com a construção da unicidade de Iahweh, outros cultos e deuses eram venerados, principalmente pelos camponeses na comunidade judaíta pan-israelita, antes do exílio (SELL, 2013, p. 186/187). Após a perda da soberania política e o desterro, as condições para o isolamento ritual desse povo foram estabelecidas por meio da racionalidade ritualista e legalista (SELL, 2013, p. 202).

O historiador italiano Momigliano, diferentemente de Weber, sugere uma combinação de fatores voluntários e involuntários que explicaria esse distanciamento ou segregação. O exílio, por exemplo, teve como consequência não apenas o fato de tornar a comunidade exílica forasteira em terras estrangeiras, mas também de alimentar a esperança de retorno à terra prometida. Terra esta que, segundo a tradição bíblica, deveria ser mantida nas mãos do "povo de Deus" como sua propriedade e seu direito, através, por exemplo, da proibição, de caráter religioso-legal, de casamentos inter-étnicos. Com base em considerações dessa ordem, Momigliano critica claramente a posição de Weber que, no seu entendimento, confunde "segregação" (a separação ritual pressupondo direitos soberanos) e "vida no gueto" (MOMIGLIANO, 1980, p. 317).

Outro autor, Fahey, considera que, nos estudos de Weber, a "marginalização" da cultura do "povo de Israel" deu-se em decorrência das imposições advindas de uma civilização central, dominante e imperial. Como Momigliano, Fahey compreende que o exílio na Babilônia poderia ser pensado como uma forma de "punição" (religiosa) que, associada às esperanças expostas por 
Ezequiel e Deutero-Isaias, resolveria o "paradoxo de status de pária da congregação judaica": o fator externo e involuntário (a dominação político-militar imperial babilônica) confirmaria o fator interno e religioso (a justiça divina de acordo com a religião de Iahweh) (FAHEY, 1982, p. 72). Dessa forma, a crença religiosa manteria a unidade do povo com base na promessa da superação da sua degradação política.

Schluchter, por sua vez, considera que a situação dos membros da comunidade exílica e do pós-exílio favoreceu as regulamentações de cunho teológico-político que justificavam a segregação, por meio de dois vetores: a determinação de prescrições ritualísticas e a revisão da tradição histórica da Torá Levítica (SCHLUCHTER, 1989, p. 195).

A partir desse levantamento teórico, cabe indagar se as questões relativas à segregação, que constam na literatura veterotestamentária, acontecem por motivos históricos e/ou legais. Ao estudar as narrativas bíblicas sobre o "povo de Israel", é possível notar que grande parte das suas diferenças com os povos situados em seu entorno concentrava-se, primordialmente, nas questões religiosas e suas emulações legais. Essas questões marcaram, posteriormente, a identidade judaica e, paradoxalmente, constituíram o diferencial que reforçou as práticas responsáveis por caracterizá-los como "povo pária" ou, de acordo com a definição menos impactante de Schluchter, como uma "organização confessional marginalizada".

Um indicativo da diferenciação por motivos históricos e/ou legais encontra-se no fato de que, segundo a narrativa bíblica, por exemplo, Iahweh em nenhuma época possuiu uma imagem para ser adorada tal como nos cultos orgiásticos promovidos por outras religiões que, em geral estimulavam a fantasia e afastavam o crente da "verdadeira fé" (MONLOUBOU, 1996, p. 286/287). A lei que se refere à imagem de Iahweh, entre outras, está localizada em Ex 20,4, onde se lê sobre a proibição da confecção de imagens do que existe nos céus, embaixo da terra e nas águas que estão embaixo da terra.

Assim, por meio desse tipo de interdição, os membros da comunidade judaíta, tornaram-se o único povo, na antiguidade médiooriental, que preconizou o culto a um deus sem imagem. Tal procedimento explica-se pelo fato de, nesse contexto narrativo, o próprio ser humano ser considerado, a "imagem de deus", ao 
contrário dos "pagãos", que identificavam seus deuses sob formas zoomórficas e metamórficas, ou a partir de fenômenos naturais. Por outro lado, encontram-se ao mesmo tempo semelhanças que aproximam a comunidade judaíta pan-israelita dos povos de seu entorno, inclusive no que se refere aos preceitos religiosos.

Dentro dessa perspectiva, a cultura babilônica, por exemplo, influenciou em grande medida a formação dessa comunidade. De acordo com Weber, a estrutura formal do Código de Hamurabi consistia em um código de mišpātîm, isto é, de prescrições de natureza jurídica, moral e cúltica, tal como pode ser visto no Deuteronômio. Ao estilo da coleção de Manu ${ }^{1}$, esses textos (verdadeira matriz jurídica), em função dos interesses da época, sofreram inúmeras adições posteriores, contendo paralelismos com o Código de Hamurabi e com os códigos que o precederam, tais como o código de leis promulgado por Lipit-Ishtar de Isin (por volta de 1870 a.E.C.), redigido em sumério, e o do reino de Eshnunna (anterior ao décimo oitavo século), editado em acádio. No entendimento de Brigth, tais paralelismos

Provam, sem deixar margem à menor dúvida, que este [código de Hammurabi] se apoiava numa tradição legal antiga, muito difundida, que remonta ao código de Urnammu de Ur e a tempos ainda anteriores. Como o código de Hamurabi, ambos [os códigos em sumério e em acádio] revelam notável semelhança com o Código da Aliança da Bíblia (Ex 21-23) e indicam que a tradição legal de Israel também se desenvolveu de semelhantes antecedentes (BRIGTH, 2003, p. 74/75).

Diante disso, embora sejam considerados preceitos divinos, percebe-se, por meio de documentação antiga, como demonstrou Weber, que o arcabouço jurídico (a Torá) do "povo de Israel" tem

1 O Código de Manu é parte de uma coleção de livros bramânicos, enfeixados em quatro compêndios: o Mahabâta, o Ramayana, os Puranas e as Leis Escritas de Manu. Escritos em sânscrito, esses compêndios fundam a legislação do mundo indiano. 
origem semelhante à dos povos vizinhos. Dessa forma, a princípio, as leis da comunidade judaíta pan-israelita, bem como o Código da Aliança - CA (e o Deuteronômio para o período do exílio) absorveram parâmetros jurídicos regulamentadores das sociedades que compunham o cenário médio-oriental. Cabe, então, a partir da tese de Weber, que acreditava na segregação ritual dos judeus advinda da observância e do respeito às prescrições rituais, a análise de algumas leis previamente selecionadas para que se possa entender sua função e o contexto em que foram elaboradas.

Diante disso, diversas são as leis que, no $C A$, caracterizam a cultura do "povo de Israel" e que serão confrontadas ao longo desse artigo. Em uma análise mais direcionada, em leis como Ex 19,5; 20,4; 23,31-33, é possível verificar a abordagem de temas referentes aos estrangeiros, aos casamentos, ao culto a Iahweh, entre outras.

Para Blum, em Ex 19,5, encontra-se o tema central do discurso da promessa da aliança, ligado à ideia da "proximidade com Deus", ou seja, o discurso está permeado de um tom "paternal" por parte de Iahweh. Esse tom conforma o modelo legal-religioso que definiu a relação do "povo de Israel" com Iahweh, prevendo punições pelos pecados e agraciamentos pela observância da lei. Trata-se de um modelo semelhante aos antigos tratados legais, do Oriente Antigo, em que se encontravam enumeradas as bênçãos e as maldições, ao final, para os que cumpriam e os que não cumpriam a lei, respectivamente (PURY, 1996, p. 217).

Ainda no texto referente à aliança, outra lei que deve ser destacada é a da passagem de Ex 20,4, proibindo esculturas, inclusive cultuais. Analisando-a pormenorizadamente, Blum faz uma comparação entre os textos de Dt 5 e Ex 20 e conclui que a primeira lei, quando Moisés proclama o Decálogo, corresponde à segunda (aos eventos que ocorreram no dia da assembleia, no monte Sinai) tanto na estrutura de base como em algumas de suas formulações. Assim, essa passagem demonstra, que os diversos códigos surgem para substituir as antigas leis, retomando o que a sociedade decide manter e alterando ou ampliando as demais em função de seus contextos.

Seguindo a leitura do texto do $C A$, chega-se ao Ex 34 que, junto com os Ex 21 e 22 (mishpatim), está entre as leis escritas mais antigas e conhecidas da história do "povo de Israel". Para Blum, mais uma vez, a encenação dessa lei retoma, no cap. 19, o início da 
perícope do Sinai, com a renovação da relação privilegiada com deus, formalmente selada com Moisés e o povo (PURY, 1996, p. 223). Dito de outra forma, Ex 34 tem por objetivo a reafirmação da aliança por meio da retomada dos eventos do Sinai.

A ação de deus expulsando os inimigos de diante do "povo de Israel", no início do v.11, é um demonstrativo de eleição divina e de reafirmação dessa aliança. Do v.14 ao 16 de Ex 34, a prescrição contra a adoração a outros deuses, cria problemas de convivência com os povos vizinhos em virtude de leis que proibiam refeição sacrificial, relações de casamento com mulheres estrangeiras que levavam, para o meio da "comunidade santa", deuses de culto sacrificial com aspecto orgiástico-sexual. Para Crusemann, "a proibição de fazer alianças procura colocar um freio em tudo isso, exigindo uma separação de mesa e cama em relação ao "morador da terra" (CRUSEMANN, 2012, p. 179). Esse é um exemplo claro de prescrições rituais que Weber considerava essencial para a definição de segregação ritual que, por fim, gerou a designação de "povo pária" para os judeus.

Tentando impossibilitar a relação com outros deuses, o ciúme do "Deus de Israel" impede as relações de vizinhança com os moradores da terra, quando se trata de refeições cultuais ou casamentos. Tal proibição do casamento, embora seja um fator importante para a teologia deuteronômica-deuteronomista (Dt 7,3), pode abranger outros fatores.

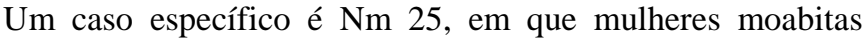
convidam o "povo de Israel" para o sacrifício aos seus deuses. Pertencente, provavelmente, ao contexto das decisões e conflitos teológicos e históricos do séc. IX a.E.C., esse texto que, de acordo com Crusemann, não é uma obra deuteronomista, não pode ser considerado modelo para Ex 34,12ss (CRUSEMANN, 2012, p. $181 / 182$ e 195$)^{2}$.

Disso pode-se deduzir que a imagem cruel de expulsão e destruição dos cananeus é esboçada em uma época de violência, um período em que a comunidade judaíta pan-israelita via-se ameaçada pelo exército assírio, desenvolvendo, assim, uma contraimagem

2 Os conflitos do séc. IX a.E.C. referem-se à invasão assíria em Israel. 
análoga (CRUSEMANN, 2012, p. 189). Essas leis são a representação do contexto histórico manipulado por uma ideologia político-religiosa de cunho pan-israelita.

As leis de Ex 34,19 e 26 determinam ainda não só que os primeiros frutos da terra e o primogênito de todo animal de criação devam ser ofertados a Iahweh, mas também que tais oferendas devam ser trazidas a uma casa de Iahweh, somente ali devendo ser celebradas as festas anuais. Essa determinação traz, como consequência, por um lado, a diminuição dos rituais aos deuses da fertilidade e, por outro, a exclusividade da adoração ao "Deus de Israel" no templo de Jerusalém (CRUSEMANN, 2012, p. 194 e 196).

Outra lei relevante encontra-se em Dt 28,43-44, cuja referência às maldições, funciona como uma espécie de motivação ao crente. Como é sabido, os tratados de vassalagem eram comuns no Oriente Próximo, desde o segundo milênio a.E.C.: "Nesses tratados [escreve Romer] o rei suserano põe por escrito diversas estipulações às quais os reis vassalos devem conformar-se. A ideia central é obrigar os vassalos a uma lealdade absoluta a seu senhor" (ROMER, 2008, p. 78). Uma parte importante desses tratados no livro do Deuteronômio são as maldições e as bênçãos responsáveis pela motivação dos vassalos e fiéis, respectivamente.

Para Romer, existem fortes indícios de elos, inclusive dependência literária, entre o Deuteronômio e os juramentos de lealdade neo-assírios, como é possível verificar, os textos veterotestamentários aproximam-se sobremaneira do modo de redação dos tratados de vassalagem do Oriente Antigo:

Especialmente importante são os adê (juramentos de lealdade) de Asaradon escritos em 672 a. C. (p. ex. (266268) Amarás Assurbanipal [...] rei da Assíria, teu senhor, como a ti mesmo.; (283-291) Este tratado [...] tu o exporás a teus filhos e netos, à tua semente e à semente de tua semente que nascer no futuro) (ROMER, 2008, p. 79). 
Para Fahey ao longo de sua formação até o pós-exílico, o culto a Iahweh conviveu pacificamente com outras divindades, muitas vezes em um mesmo santuário, principalmente nas zonas agrícolas da Palestina/Canaã (FAHEY, 1982, p. 65). Weber lembra que, na narrativa de Labão (Gn 31,19), por exemplo, todos os membros de pleno direito de uma linhagem dispunham, em sua casa, de um lugar de culto ou ídolos domésticos, conhecidos como Baals. Dessa forma, principalmente nas regiões agrícolas da Palestina, o culto a Iahweh sobreviveu por muito tempo junto aos cultos a outros deuses e astros ligados à vegetação e à natureza, sendo, muitas vezes, venerados, com naturalidade, dentro de um mesmo santuário (WEBER, 1987-88, p. 166,175 e 183).

Já para Finkelstein e Silberman, no séc. VII a.E.C., os líderes judaítas declararam que todos os traços da cultura de adoração da religião estrangeira eram a causa das desgraças ocorridas em Judá (FINKELSTEIN, 2003, p. 12). O caráter orgiástico dos cultos de Baal, por exemplo, com seus ritos etílicos e sexuais, foram radicalmente condenados, sendo que, nesse mesmo período, foram destruídos vários santuários rurais, ideia compartilhada por Weber (WEBER, 1987-88, p. 219).

No Exodo, encontra-se um preceito que proíbe a aliança com outros povos e seus respectivos deuses, devendo todos ser expulsos e a total destruição desses povos inimigos e de seus templos um exemplo dos anátemas impostos por Iahweh às "falsas deidades", como se comprova em Ex 23,31-33 e 34,15.

Já em Levítico, além de proibições, como a de seguir as normas e os costumes dos povos vizinhos ( $\operatorname{Lv} 18,3-4$ e 29) e de oferecer um filho a Moloc ( $\operatorname{Lv} 20,2)$, existe a obrigação da consagração dos filhos e bens a Iahweh (Lv 20,26). É certo que tais preceitos reforçam a crença de que esse é o povo escolhido entre os demais, tornando-se o "povo de Israel" devedor de Iahweh, tendo por obrigação reverenciar somente a ele e confiar em seu auxílio.

Em tal contexto, o Deuteronômio evidencia uma grande mudança no entendimento e na forma da religião atribuída ao "povo de Israel". Se antes os outros deuses, tidos como falsos pela narrativa, eram considerados "inferiores", a partir do Dt 4,35, Iahweh torna-se o 
único deus do universo, "além dele não existe outro"’3. A crença em outros deuses, no entanto, não deixou de existir somente por meio da redação veterotestamentária.

Seguem-se outros exemplos de leis deuteronômicas que enfatizam a relação de Iahweh com o "povo de Israel": em Dt 6,4, afirma-se a unicidade de Iahweh; em Dt 7,1-4, estabelece que o "povo de Israel" é separado dos demais povos (eleição); e em Dt 29,9-14, refere-se à aliança em Moab, passagem em que os estrangeiros são claramente diferenciados do restante do "povo de Israel".

Para Weber, quando se analisa Dt 6,4 e outras leis que se referem à essência de Iahweh, entende-se que este continuou como um deus sem complemento feminino, adorado sem imagens e carente de um culto derivado da orgiástica e da magia mitológica dos demônios que estimulava a fantasia do crente e a poesia (WEBER, 1987-88, p. 256). Sabe-se hoje, todavia, por meio da pesquisa arqueológica, que existe além da possibilidade de ter havido um complemento feminino para Iahweh, as narrativas em que ocorrem lutas contra deuses/demônios no $A T$ (Gn 32,23). Ainda em relação a Dt 6,4, de acordo com os redatores, pode-se afirmar que, no texto bíblico, a existência de outros deuses no período antigo nunca foi expressamente afirmada, mas à medida que Iahweh tornou-se o senhor de Israel, a negação de outros deuses tidos como falsos sistematizou-se (AT, 1992, p. 266).

Segundo Romer, a ideologia de separação em relação às nações que habitavam a terra prometida pode ser encontrada em leis expostas em Dt 7,1-6.22-26 e 9,1-6, as quais são estritamente ligadas ao tema do santuário único, como se vê em Dt 12 (ROMER, 2008, p. 68). Romer acredita que a última revisão dos textos de Dt 12,2-7 e 207, sobre o discurso acerca da separação dos outros povos pertence, provavelmente, a uma nova perspectiva no contexto do imaginário deuteronomista, no período persa (ROMER, 2008, p. 131). Segundo o autor, "os v.2-7 revelam uma ideologia de segregação. O principal

3 No Decálogo havia a proibição do culto a deuses estrangeiros, considerados inferiores a Iahweh. Por meio de Dt 4,35 esses deuses passam a não mais existir. Cf. O Antigo Testamento. 2011, p. 264. Neste texto, com exceção da s citações, a palavra deus é utilizada na forma minúscula para evitar a conotação religiosa do deus do monoteísmo como o salvador e dos deuses pagãos como falso. 
tema da lei da centralização transformou-se agora na proibição e destruição daquilo que é considerado como cultos ilegítimos" (ROMER, 2008, p. 70).

Consequentemente, de acordo com Josefo, em sintonia com as narrativas de sua época, para evitar a idolatria e o abandono das leis em virtude de um relacionamento mais próximo com os "estrangeiros pagãos", o "povo de Israel" teria destruído os povos inimigos (como os camponeses que adoravam os "falsos deuses"), seus templos, altares e bosques consagrados a esses deuses (JOSEFO, 2007, p. 217).

No mesmo sentido, para Weber, as concepções religiosas começaram a adquirir um racionalismo dirigido por um deus universalista, necessitando-se de explicações tanto para as ameaças políticas quanto para as derrotas sofridas pelo "povo de Israel". Como conclusão lógica desse racionalismo, por meio do $b^{e} r \hat{t}^{4}$, Iahweh tinha o direito de castigar Israel em caso de desobediência aos seus mandamentos.

Dessa forma, à medida que a concepção de deus ganhou status universalista, Israel transformou-se numa nação eleita, e a $b^{e} r \hat{t} t$ transformou-se em uma promessa unilateral divina, da qual nascia o amor gratuito por parte de Iahweh e a abominação aos cultos estrangeiros. Por meio do status de deus universal, Israel adquire posição privilegiada em relação aos demais povos, tornando-se o "povo eleito", com direitos e deveres, rituais e éticos, que os diferenciavam (WEBER, 1987-88, p. 366/367).

Segundo Freitas, no exílio babilônico (séc. IV a.E.C.), quando os exilados viviam agrupados em lugares específicos para eles, os judeus teriam se transformado em um "povo-pária, autossegregado, ressentido, ritualista, legalista, orientado por uma ética dual (isto é, com um padrão de comportamento em relação aos judeus e outro em relação aos gentios)" (FREITAS, 2007, p. 109). Essa autossegregação deve-se ao fato de sacerdotes e mestres da Torá terem considerado importante o estabelecimento de barreiras rituais,

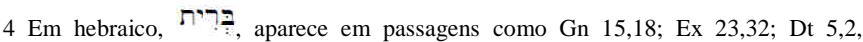
significa aliança, pacto, acordo, contrato; pode ser usado em campo profano ou religioso. Toda palavra em hebraico, utilizada neste texto, segue a escrita segundo o dicionario hebraico de Monloubou e Du Buit. 
por meio da codificação unificada dos quatro primeiros livros do $A T$ e da redação inicial do Deuteronômio, a começar pela proibição e dissolução dos matrimônios mistos.

Josefo sugere que as leis supostamente criadas por Moisés (mas codificadas pelos deuteronomistas), como a proibição do adultério, somada à proibição de casamentos com estrangeiros, representou uma opção do "povo de Israel" pelo separatismo com relação aos "gentios" (JOSEFO, 2007, p. 186) .

Weber, entretanto, sugere que, no judaísmo tardio, a circuncisão, o descanso sabático e o šabbāt ${ }^{6}$, entre outros costumes, passaram a ser observados com mais rigor, para garantir a radical separação entre os judeus e os "gentios" (WEBER, 1987-88, p. 416/417). Para esse mesmo autor, contudo, a transformação dos judeus em um "povo-pária"

Teve início ainda antes do exílio (586 a.C) e consumouse com a Restauração judaica, após o exílio (538 a.C), tal como relatada nos livros de Esdras e Neemias. A partir de então, iniciou-se um processo de auto-segregação, pois não era mais concedido aos judeus o direito de se casar com gentios, e os casamentos 'mistos' já existentes foram desfeitos por decreto (FREITAS, 2007, p. 122).

De qualquer forma, é plausível afirmar que as prescrições rituais da Torá deram base para a autossegregação do "povo de Israel" difundida na época deuteronômica, lembrando, todavia, como faz Weber, que esse processo atingiu seu auge com a redação dos códigos de Esdras e Neemias. Originalmente formado também por forasteiros, o "povo de Israel" tornou-se "uma comunidade

5 Flávio Josefo, também conhecido pelo seu nome hebraico Yosef ben Mattityahu (יוסף e, após se tornar um cidadão romano, como Tito Flávio Josefo foi um historiador judaicoromano, que registrou a destruição de Jerusalém, em 70 d.C., pelas tropas do imperador romano, período em que viveu. As obras de Josefo fornecem um importante panorama do judaísmo no século I. Cf. Flávio Josefo, Wikipédia.

6 Em hebraico, 2 , repouso, sábado. 
confessional ritualmente segregada, cujos membros são recrutados pelo nascimento e pela admissão dos prosélitos" (WEBER, 1987-88, p. 386). Dessa forma, não foi o fator consanguíneo ou linguístico que distanciou o "povo escolhido" dos demais vizinhos (canaanitas, amoritas, entre outros), mas a tradição religiosa com a qual haviam celebrado um compromisso sagrado. Para Weber o separatismo do "povo de Israel" tem sua origem nas questões legais advindas da ritualística religiosa. Deve-se lembrar, no entanto, que Weber desconsidera a transformação dessas leis no decorrer da história desse povo, suscitando a crítica por parte de Arnaldo Momigliano (MOMIGLIANO, 1980).

Ao longo deste artigo, a ênfase tem sido dada ao "povo de Israel", atendo-se à análise histórica e arqueológica que sugere, contudo, a inexistência desse povo tal como descrito na Bíblia. Devese esclarecer, que as reflexões a seguir sobre quem era considerado membro desse povo serão balizadas pelo texto veterotestamentário, ou seja, a partir da definição de "israelita", no $A T$.

O "israelita" veterotestamentário era considerado o indivíduo de origem consanguínea ou da terceira geração de convertido que havia observado uma vida correta, possuindo, assim, status privilegiado. Se, por um lado, a lei sagrada, a princípio, estabelecia os mesmos preceitos para o "israelita" e para o ger (forasteiro ou estrangeiro), por outro lado, direitos e obrigações separavam os nativos dos estrangeiros ${ }^{7}$. Dessa forma, ainda que o Êxodo determine uma única lei para o cidadão e o imigrante (consta também em $\mathrm{Nm}$ 9,14), para Weber há uma diferenciação legal dos gerîm $^{8}$, os quais "não eram parte dos benê Jiśrā'el que estavam sujeitos à leva militar,

7 Weber afirma que ger também era conhecido como nǒkri (yrlk.n", Rt 2,10; Gn 31,15; Dt 14,21, estrangeiro, forasteiro, entretanto, no hebraico, essas palavras tem conceitos diferenciados sendo utilizado normalmente para definir mulheres estrangeiras e prostitutas).

$8 \mathrm{Em}$ hebraico, $=$, plural de ger (forasteiro, peregrino, imigrante, hóspede, opõe-se a nativo, portanto pode ser tanto gentio quanto um israelita de outra tribo; juridicamente assemelhavam-se aos órfãos e viúvas).

Israel.

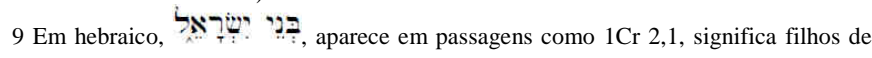




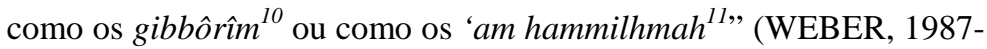
88 , p. 59).

De acordo com as narrativas de Siquem e Diná, portanto, os gerîm eram segregados ritualmente e excluídos do convívio entre os iguais. Exemplo desse tratamento é encontrado nas leis do $A T$, mais especificamente em Ex 22,25, que, ao condenar a exploração do pobre, refere-se ao "israelita" em sentido pleno (am). Dessa forma, segundo Weber, "um israelita, que está endividado não deve ser tratado como um servo, mas como um trabalhador livre" (WEBER, 1987-88, p. 94), ao contrário do estrangeiro, que poderia vir a ser servo ou escravo. Embora, no Exxodo, possa-se identificar a proibição de submeter o estrangeiro e o oprimido (Ex 22,20 e 23,9), embora ainda, no Levítico, conste a obrigação de amar o estrangeiro como um compatriota ( $\operatorname{Lv} 19,34)$, impondo o mesmo tratamento jurídico para naturais ou estrangeiros ( $\mathrm{Lv} 24,22)$, verificam-se, no $C A$, diversos preceitos que estigmatizam os estrangeiros e os diferenciam do "povo de Israel". Também em Êxodo, no cap. 23,9, há referência aos deveres para com os inimigos ou estrangeiros.

Como já se afirmou, as leis de Ex 21-22 (mishpatim) estão entre as leis escritas mais antigas e conhecidas do "povo de Israel", podendo ser datadas do séc. VII a.E.C. Como se comprova, no $C A$, a escravidão, tratada nos mishpatim, não existiu antes da época do estado judaíta já que, até então, a produção tanto no reino de Israel quanto no de Judá ainda não se caracterizava pelo trabalho dependente. Só no período após o estabelecimento do pan-israelismo, a escravidão e o direito dos escravos tornaram-se relevantes (CRUSEMANN, 2012, p. 217/218 e 235).

Importante ressaltar que, quando os textos veterotestamentários se referem a estrangeiros, também conhecidos como ger r, faz-se alusão a pessoas que não pertencem a um lugar desde sua origem ou que nele não têm parentes ou propriedades, de forma que estrangeiros podem ser tanto os próprios "israelitas", que vivem nas áreas de outras tribos, quanto outros povos ou membros de

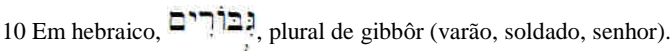

11 Em hebraico, significa povo guerreiro, combatente, soldado. 
outras religiões. De acordo com Weber, o próximo é considerado o compatriota assim como o companheiro na fé. Nesse sentido, o amor ao próximo era visto como o amor ao irmão de fé (WEBER, 1987-88, p. 368).

Nos séc. VII e VI a.E.C., Judá recebeu grande leva de imigrantes refugiados do reino do Norte, em virtude da sua destruição pelos assírios. As fontes arqueológicas e literárias atestam que esse processo fundamenta a teoria de que o $C A$, com sua problemática sobre os estrangeiros e o direito social, deve ser datado nas últimas décadas do séc. VIII ou início do VII, e não antes dos acontecimentos que resultaram na destruição da Samaria, em 722 a.E.C. (CRUSEMANN, 2012, p. 259/260 e 278). O CA seria, portanto, uma narrativa resultante da catástrofe do reino do Norte. Ademais, apesar de as leis do Deuteronômio e as Sacerdotais garantirem certa proteção aos estrangeiros, independentemente de sua origem ou religião, ambas possuíam algumas contradições (CRUSEMANN, 2012, p. 261/262).

No Levítico, por exemplo, permite-se aos "naturais" - leia-se "israelitas" - possuir servos e escravos como herança perpétua, desde que provindos de outras nações. Por outro lado, proíbe-se a imposição de trabalho escravo a um irmão que se vende devido à pobreza e/ou sua venda como escravo a terceiros (Lv 25,39-42 e 44-46). Dessa forma, essa lei faz clara distinção entre naturais e estrangeiros, visto que a venda de escravos estrangeiros a terceiros não era condenada. A lei do Lv 19,34, por sua vez, estabelece prescrições morais e cultuais que deveriam ser observadas também pelos estrangeiros que viviam entre os "israelitas" bíblicos.

No Livro de Números, em que os estrangeiros são especificamente citados, encontram-se outras leis de natureza cultual, nas quais são estabelecidas as mesmas obrigações e costumes para naturais e estrangeiros: Nm 9,14 (sobre a festa da Páscoa); Nm 15,1516 (sobre a oblação que acompanha os sacrifícios); $\mathrm{Nm} \mathrm{19,10} \mathrm{(a}$ respeito das cinzas da novilha vermelha); e Nm 35,14-15 (sobre as cidades de refúgio). Essas leis cultuais podiam facilmente ser observadas por um "israelita" que estivesse fora de sua tribo de origem (estrangeiro). Por outro lado, um indivíduo que não fosse adepto da fé em Iahweh ou que não fosse convertido teria problemas em relação à observação de algumas das prescrições, especialmente 
as de caráter cultual, como a circuncisão obrigatória para festejar a Páscoa.

O Deuteronômio é outro compêndio de leis que, junto ao Exxodo e ao Levítico, apoia a usura para com os não adeptos da fé javista, embora lhes atribua alguns direitos e proíba o trabalho aos sábados, tanto aos "naturais" quanto aos estrangeiros (Dt 5,12-14) ${ }^{12}$. Ao lado dessas leis, que garantem respeito e auxílio mínimo aos estrangeiros que vivem entre os "israelitas", outras são prescritas no Deuteronômio: em Dt 15,3, permite-se a exploração do estrangeiro, mas proíbe-se a cobrança de empréstimo feito ao irmão de fé; em Dt 17,14 e 15, proíbe-se a nomeação de um rei estrangeiro; em Dt 23,21, autoriza-se o empréstimo a juros a estrangeiros, no entanto proíbe-se a cobrança de juros de um irmão; em Dt 23,3, proíbe-se a presença de bastardos (descendentes de matrimônios entre "israelitas" e estrangeiros, até sua décima geração) nas assembleias cultuais; em Dt 23,8-9, exige-se respeito ao edomita ou egípcio; em Dt 24,14, proíbese a opressão ao assalariado pobre, seja "natural" ou estrangeiro, que vive nas terras do "povo de Israel"; em Dt 24,16, estabelece-se que cada um será executado por seu próprio crime, estabelecendo, assim, a responsabilidade individual; em Dt 24,19-21, estabelece-se como pertencente ao estrangeiro, órfão ou viúva, o que for esquecido na colheita ou dela sobrar; por fim, em Dt 27,19, maldiz-se aquele que perverte o direito do estrangeiro, do órfão e da viúva.

Outro ponto relevante para esta pesquisa pode ser encontrado no Gênesis, em que diversas passagens, além de condenarem o casamento com estrangeiros, determinam os direitos da mulher obtidos por meio do matrimônio. Tanto a narrativa do casamento de Isaac (Gn 24,3-4) quanto a da violência contra Diná (Gn 34) são usadas por Oseias (profeta que viveu possivelmente no reino de Israel antes da queda de Samaria) como tradição oral conhecida de todos os seus ouvintes, donde se conclui que os textos de Gn 25-35 são de tempos antigos (PURY, 1996, p. 212).

Quanto à primeira narrativa, de quando Abraão envia a seus parentes um servo para que este escolha uma mulher de mesma pertencendo às camadas mais antigas do Deuteronômio. Cf. CRUSEMANN, op. cit., p. 73. 
origem para casar com Isaac, tem-se, possivelmente, a primeira demonstração de segregação (Gn 24,3 e 4). Na segunda narrativa (Gn 34), mais do que a rejeição de parentesco por casamento e a intenção de homicídio por parte dos irmãos de Diná, o v. 13, de Gn 34, demonstra, segundo Crusemann, o descumprimento de uma promessa: não se trata, portanto, do casamento com estrangeiros, mas da quebra de um contrato de forma premeditada, com dolo, como foi feita pelos irmãos da moça violentada (CRUSEMANN, 2012, p. 107).

Pode-se perceber, nesse sentido, o uso do dispositivo de não aceitação do estrangeiro, por meio do matrimônio, em todas essas narrativas, como no relato sobre Diná, quando pedida em casamento: seus irmãos afirmam ser uma desonra para a família aceitar o casamento de uma filha com um homem incircunciso (Gn 34,14 e 15).

Diferentemente da narrativa de Isaac, que procura entre os seus uma esposa, a de Judá, em Gn 38, ressalta a união entre membros do "povo de Israel" e estrangeiros, já que Judá toma por esposa uma mulher cananeia, pagã, cuja conversão não é relatada no texto e escolhe Tamar, cuja origem não é mencionada, como esposa para um de seus filhos, mostrando controvérsias no conjunto da obra veterotestamentária. Outra passagem, que segue a mesma direção da narrativa de Judá, refere-se a Esaú, quando este não pede permissão ao pai para casar, sabendo que ele não aprovaria a aliança com estrangeiros (JOSEFO, 2007, p. 104).

Outro exemplo é o caso de José que, no Egito, casa com a filha do sacerdote de On, e com ela tem filhos (Gn 41,50-52) ${ }^{13}$. Esse caso pode ser usado como exemplo tanto para condenação da união entre membros do "povo de Israel" com "pagãos" quanto para a questão relativa aos filhos considerados bastardos gerados dentro dessas uniões.

Existem ainda leis que asseguram a inviolabilidade da mulher virgem, estando determinado em Ex 22,15s que, se uma virgem for violada, o violador deverá pagar o dote e casar com ela. A questão nessa lei, contudo, não é a segurança da mulher, mas a relação de Menashé. 
propriedade, ou seja, o valor do dote que deverá ser pago ao pai da moça (CRUSEMANN, 2012, p. 347).

No Levítico, os membros do "povo de Israel" têm por obrigação tomar por esposa somente as virgens do seu povo (Lv 21,13-15), visto que, na interpretação religiosa, se a mulher for profana, como viúvas, mulheres repudiadas ou prostituídas, além de estrangeiras, sua descendência será profana.

De acordo com Weber, foi no exílio que se observaram as proibições de casamentos mistos, consumando, portanto, a segregação ritual da comunidade (WEBER, 1987-88, p. 365 e 376). Somente no pós-exílio, por meio da redação sacerdotal, verifica-se a dissolução dos matrimônios mistos já existentes.

Em Números, no último capítulo (Nm 36,5-9), que versa sobre o casamento das filhas do "povo de Israel" e a manutenção da propriedade por meio da herança, Crusemann destaca dois momentos: enquanto, no primeiro, a norma dirige-se ao caso isolado, no segundo, dirige-se a uma regulamentação geral. Isso demonstra que, nos casos não previstos, ou não regulamentados pelo sistema jurídico ou pelas normas tradicionais vigentes, a decisão tornava-se precedente fundamental para a normativa jurídica do Estado (CRUSEMANN, 2012, p. 149/150).

Diante disso, para Crusemann, Nm 36 foi elaborado no período final da redação do Pentateuco, isto é, no pós-exílio. Deve-se ressaltar também que o conteúdo da norma legisla a favor da mulher, mas com ressalvas: o direito de herança das filhas está vinculado ao casamento com um homem de sua escolha, desde que pertencente ao clã da tribo paterna, já que a herança não deve passar de tribo para tribo $^{14}$.

No Deuteronômio, Iahweh proíbe a aliança e os matrimônios mistos (Dt 7,1-5). Nesse mesmo livro, encontram-se estabelecidas as seguintes normativas: condições para tomar por esposa uma prisioneira de guerra (Dt 21,10-14); proibição da entrada de um bastardo até sua décima geração na assembleia de Iahweh (Dt 23,3);

14 Josefo destaca que as filhas de Zalfate terão o direito de receber sua herança desde que se casem com homens membros de sua tribo; se, por outro lado, casassem com membros de outra tribo, esse direito lhes seria negado de modo que cada tribo conservasse os bens que pertencesse a cada um de seus membros Cf. JOSEFO, op. cit., p. 215. 
autorização à terceira geração de um edomita ou egípcio para entrar na assembleia de Iahweh (Dt 23,8 e 9); determinação de que quando um irmão deixa viúva sem descendentes deverá o cunhado casar-se com ela para garantir o nome aos descendentes e manter as terras na posse da tribo (Dt 25,5) ${ }^{15}$. Dessa forma, Dt 25,5-10, também conhecida como lei do levirato, trata da questão da herança e da tradição do nome. A norma dita que o irmão do falecido deverá gerar descendentes com a viúva sem filhos está diretamente relacionada tanto com o direito à herança da criança e da mãe quanto com a importância de perpetuar o nome da estrutura familiar patrilocal (CRUSEMANN, 2012, p. 354).

Só na época do exílio, a família é pensada como a representação física do "povo de Israel" e de sua religião, já que, longe de sua terra de origem e de seu Estado, os membros desse povo ligavam-se à promessa da aliança por meio de ambas. Para isso, as leis que garantiam as antigas regras de endogamia e proibiam as uniões não tradicionais adquiriram importância radical a ponto de proibirem e, em alguns casos, anularem casamentos mistos, principalmente no retorno à terra prometida (CRUSEMANN, 2012, p. 407).

Segundo Graetz, a abolição do casamento misto e a expulsão das mulheres não judias bem como de seus filhos deram origem a um sentimento de ódio contra os judeus. Para Sand, aos olhos do profeta Esdras, em Esd 9, o casamento misto era um pecado horrível (SAND, 2011, p. 143).

Segundo Doubnov, a abolição dos casamentos mistos foi, no entanto, uma tentativa de ampliar o separatismo nacional, impedir que a pureza da cultura judaica, ainda frágil e em formação após o retorno à terra prometida, absorvesse os cultos religiosos do Oriente (SAND, 2011, p. 173/174).

As leis dos alimentos, por sua vez, foram, igualmente, de grande importância na estrita observância das práticas religiosas judaicas. As proibições nutricionais podem ser encontradas na nome perpetue e seus bens sejam mantidos na família. Cf. JOSEFO, op. cit., p. 225. 
legislação sacerdotal, que criou dificuldades extraordinárias para as práticas alimentares (WEBER, 1987-88, p. 377).

A ritualização dos costumes alimentares dificultou o convívio com os demais povos, embora o preceito da segregação de qualquer "pagão" recaísse somente sobre o "israelita" que pretendesse realizar um ato de culto (Jo 18,28). No Êxodo, em que o próprio deus faz conhecer suas leis, existem as que distanciam cada vez mais o "israelita" de seus vizinhos: em Ex 12,19, o que come pão fermentado, durante a Festa dos Ázimos, será eliminado do "povo de Israel"; em Ex 12,43, não é permitido a nenhum estrangeiro, durante a Páscoa, comer do alimento ritual; em Ex 12,48 e 49, o que quiser participar da celebração da Páscoa deverá circuncidar todos os varões de sua casa, convertendo-se à fé em Iahweh. Essa última norma consta também em Nm 9,14.

No Ex 12,19, está também a lei que proíbe consumir carne com vida, o que para o "povo de Israel" significa o consumo de sangue. Segundo Crusemann, essa regra alimentar é, provavelmente, antiga, sendo a base do Ex 22,30 e recebendo nova interpretação em Dt 12 (CRUSEMANN, 2012, p. 402).

No Levítico, por sua vez, há proibições alimentares essencialmente ligadas ao culto, tais como: obrigação de oferecer um holocausto em sacrifício na entrada da Tenda da Reunião ( $\operatorname{lv} 17,8$ e 9). Nesse livro, encontra-se não só a proibição de ingerir sangue, porque, de acordo com a Torá, a alma reside no sangue do ser, e esta pertence a deus (Lv 17,10), mas também a obrigação de derramar o sangue da caça e cobri-lo com terra, pois nenhum ser deve ficar insepulto (Lv 17,13). Há ainda a obrigação de banhar-se com água e lavar as vestes após comer um animal morto ou dilacerado ( $\mathrm{Lv}$ 17,15); proibição da prática dos costumes do Egito e de Canaã (Lv 18,3 e 4). A punição ao transgressor de quaisquer desses preceitos era o degredo. Além disso, em Levítico, nas regras referentes à pureza e à impureza, verifica-se uma lista de animais aquáticos, terrestres e alados considerados puros, sendo, portanto, passíveis de ser ingeridos.

Por último, no Deuteronômio, há apenas uma lei referindo-se à alimentação. Trata-se do Dt 14,21, que proíbe a ingestão de animais cuja causa mortis não possa ser identificada.

Segundo Finkelstein e Silberman, os ossos recuperados nas antigas vilas das regiões montanhosas da Palestina, do período do 
Ferro, diferem dos demais encontrados em outras regiões: não foram encontrados ossos de porco, significando que eles não eram cozidos, comidos ou mesmo criados nas regiões que abrangiam os reinos de Judá e de Israel, de modo que tal proibição não era de natureza ambiental ou econômica. Provavelmente, antes mesmo da composição do texto bíblico, séc. VII a.E.C., os habitantes dessas regiões já haviam determinado a proibição de comer carne de porco, por meio de normas dietéticas. De fato, essa é a prática mais antiga e arqueologicamente atestada que se tem do "povo de Israel", por meio da qual é plausível supor a existência de uma prática específica compartilhada entre as diferentes populações das aldeias montanhosas, a oeste do Jordão, que constituem as comunidades protoisraelitas (FINKELSTEIN, 2003, p. 169/170).

Além das leis bíblicas relativas à alimentação, existem as que abordam diferentes temas, como prescrições rituais, observância do sábado, entre outras, encontradas a partir do livro do Gênesis: Gn 2,4a, 4,26, 11,31, 13,14-18, enfatizam o caráter de povo especial, escolhido e separado dos demais povos que a narrativa do $A T$ constrói ao longo do seu texto.

A aliança, no $A T$, com a descendência de Abraão, é, segundo o texto bíblico, a primeira e significativa diferenciação estabelecida, por meio de uma celebração, entre o "povo de Israel" e o restante dos povos. Segundo Pury, os relatos de Abrão podem ser fragmentos de reflexão teológica característicos das comunidades judaicas da época pós-exílica, de forma que Gn 12-13 (emigração de Harã e teofanias de Siquém e de Betel) provavelmente são uma apropriação da tradição ou do ciclo de Jacó, não podendo, portanto, ser atribuídos a uma tradição antiga (PURY, 1996, p. 208/209).

Por outro lado, prevalecia, por volta do séc. VI a.E.C., a tradição de um patriarca, Abraão, eleito por deus e ancestral do "povo de Israel", como sendo o primeiro a tomar posse da terra, como narra a passagem de Is 51,2. De acordo com Pury, a "tradição já devia estar suficientemente gravada na consciência coletiva para ser conhecida tanto dos exilados como dos que haviam permanecido na terra" (PURY, 1996, p. 211).

Em relação às prescrições cultuais e às festas, os textos de Ex 12,43 e 48-50 referem-se à cerimonia e à festa da Páscoa, sendo que, 
nos vv.43-50, estão estipulados, entre outras, as condições para que os estrangeiros participem e preparem a ceia.

O texto que segue em Ex 12-16 traz como temática a "festa do êxodo" (Pessah ${ }^{16}$ e Massot $\left.{ }^{17}\right)$ que, no período persa, introduz uma dimensão temporal no próprio texto, já que, em sua origem, o êxodo significava a libertação da morte, e a Páscoa ainda não era uma festa, mas um rito apotropaico de proteção, ou seja, um dos sinais de libertação entre os protoisraelitas e judaítas. Para Zenger, o Ex 12,1s interpreta a saída do Egito como o verdadeiro começo da história de Israel (PURY, 1996, p. 253 e 263).

Entre as leis de prescrições cultuais e relativas às festas que fazem referência aos "israelitas" e aos estrangeiros arrolam-se: Lv $16,29-30 ; 17,8-10 ; 13$ e $15-16 ; 24,16$ e 22 , segundo as quais ambos têm os mesmos direitos; Dt 27,19, segundo a qual deus maldiz aquele que perverte o direito do estrangeiro, assim como o da viúva e o do órfão.

Uma característica importante dos judeus é a observância, supostamente desde a origem desse povo, do Shabat, dia do senhor ou dia santo, melhor identificada em Nm 15,32-36. Segundo Crusemann, o fato de o infrator, não observando o sábado, ter sido posto sob guarda, até o momento da decisão sobre seu futuro, demonstra a inexistência inicial da norma jurídica para tal infração que, depois de tomada a decisão torna-se prescrição para os demais casos (CRUSEMANN, 2012, p. 148). Dito de outra forma, Nm 15 é uma lei nova que não determina punição para o delito cometido, sendo, portanto, uma prática que começa a se firmar no período da elaboração da escritura veterotestamentária, mais especificamente com os textos deuteronomistas. Dessa forma, a observância do sábado como um dia santo não era algo que acontecia desde a origem do "povo de Israel", mas uma norma elaborada ao longo da história e do desenvolvimento dos costumes.

\footnotetext{
16 Em hebraico, Páscoa, ritual da Páscoa.

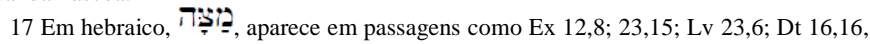
significa pães ázimos ou festa dos pães ázimos como também era conhecida a Páscoa visto que não era permitido ingestão ou feitura de pães com levedo.
} 
De acordo com Romer, em Dt 5,12-16, o texto que determina guardar o sábado por parte do "povo de Israel" e daqueles que vivem em seus espaços

mostra a novidade da compreensão do sábado como o sétimo dia da semana, que provavelmente surgiu durante o período exílico (...). Sua transformação talvez esteja ligada à invenção de um 'tempo sagrado' em vez do 'espaço sagrado' (templo), que no exílio não era acessível (ROMER, 2008, p. 130).

Em virtude da perda da terra santa, foi necessária a criação de dispositivos vinculando o povo à religião e à aliança para que, permanecendo unidos, não perdessem sua identidade de "povo escolhido". Para tanto, o vínculo à família bem como a observância das leis, que limitavam a interação com estrangeiros, foram melhor sistematizados com o objetivo de serem postos em prática.

Pode-se verificar, dessa forma, ao longo do estudo do Pentateuco, que em diversas passagens encontram-se as leis que dificultam o convívio de judeus com as populações vizinhas. Ainda que se leve em conta que toda a documentação sobre o "povo de Israel" atualmente disponível, inclusive a Bíblia como narrativa escrita, foi produzida cerca de 1500 anos após o suposto surgimento do grupamento patriarcal, é possível perceber a singularidade das proposições contidas nesse livro. Essa possibilidade explica-se porque a própria história permite constatar um maior ou menor afastamento e diferenciação dos judeus face às outras nações, em função de uma autêntica e efetiva crença na eleição divina.

Avançando no tempo para melhor compreender a formação desse povo e levando-se em conta o fenômeno do exílio, após o período de adaptação, quando a comunidade judaica espalhou-se entre as diferentes comunidades estrangeiras, emerge o reconhecimento da identidade religiosa de forma mais pontual e rigorosa. $\mathrm{O}$ afastamento da terra prometida traz como consequência a afirmação de uma fé atenta à prática dos princípios religiosos. 
Durante o exílio, com a desmilitarização, foram paulatinamente eliminadas as diferenças entre os judeus de pleno direito e os gerîm $^{18}$. Com a constituição da comunidade da $g \hat{o} l a \bar{h} h^{19}$, na qual os judeus, destituídos de seus antigos domínios territoriais, isolaram-se em assentamentos próprios, em territórios estrangeiros, consolidou-se seu próprio ideal religioso que, mais tarde, transformálos-ia em um povo forasteiro, internacionalmente disperso.

A destruição dos reinos de Israel e de Judá, bem como a consequente perda de território, foram vistas como o "castigo de deus" em função da desobediência às suas leis, como previa a $b^{e}$ rît: "como antes, Javé permanece indiferente em relação a outros povos. Mas ele os usou como "flagelo de Deus"” (WEBER, 1987-88, op. cit., p. 366). Foi imposta a observância da ética cotidiana e dos preceitos religiosos-normativos na tentativa de se redimir dos pecados cometidos para, novamente, obter as graças de deus, um deus que se torna o único deus de Israel, regendo todos os povos, mas sendo cultuado cada vez mais individualmente. À medida que Iahweh convertia-se no deus supremo do céu, da terra e dos povos, como já dito, um deus único e universal, a comunidade exílica concebia-se como o "povo eleito", aquele que um dia terá o poder de ser o e guia espiritual de todos os povos.

Dessa forma, como destaca Freitas, para Weber, as promessas messiânicas da doutrina legalista foram responsáveis por erigir barreiras étnicas e de nascimento entre a comunidade judaica, que se autoproclamava "povo eleito", e os demais povos (FREITAS, 2010 , p. 17). A promessa de que a comunidade de "Israel" prevaleceria sobre as demais nações e que, após o exílio babilônico, foi responsável pela autossegregação, orientou-se por uma ética dual em que os "israelitas" tinham um padrão de comportamento em relação a seus iguais e outro em relação aos "gentios" (FREITAS, 2010, p. 21).

18 Essa desmilitarização ocorreu com a desarticulação militar da confederação israelita, concebida ainda no processo de formação das tribos para a proteção destas. Para maiores detalhes sobre a confederação israelita verificar cf. WEBER, 1987-88, op. cit., p. 49/50.

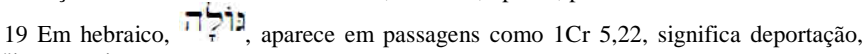
desterro, exílio, expatriação. 
O problema, no entanto, consiste no fato de Weber identificar a existência desse comportamento, a que ele chama "pária", ainda antes do exílio. De fato, existiram movimentos, como o profetismo "israelita", que defendiam a observação da lei em sua forma minimalista. Esses movimentos, em contrapartida, não atingiram a maioria da população, de origem camponesa, que ainda cultuavam seus deuses familiares e outras divindades agrárias além de Iahweh, mesmo durante o contexto da comunidade judaíta pan-israelita.

Nesse sentido, o "reino da legalidade", como chamou Schluchter, foi instituído como observância mecânica de normas concretas somente após 538 a.E.C., no período da "Restauração Judaica", isto é, no pós-exílio, quando então se suspende o direito dos "israelitas" de casarem com "gentios" e se impõe, pela via da lei bíblica, a dissolução dos casamentos mistos realizados ao longo do exílio (FREITAS, 2010, p. 22).

\section{Referências Bibliográficas}

BRIGTH, John. História de Israel. $7^{\text {a }}$ edição, São Paulo: Paulus, 2003.

CRUSEMANN, Frank. A Torá: teologia e história social da lei do Antigo Testamento. Petrópolis, RJ: Vozes, 2012.

FAHEY, Tony. Max Weber's Anciente Judaism. The American Journal of Sociology, The University of Chicago Press, vol. 88, $\mathrm{n}^{\circ} 1$, p. 62/87, july, 1982.

FINKELSTEIN, Israel; SILBERMAN, Neil Asher. A Bíblia não tinha razão. São Paulo: A Girafa Editora, 2003.

FREITAS, Renan Springer de. A sociologia da religião como recapitulação da teologia cristã: Weber e as raízes proféticas do racionalismo ocidental. RBCS, São Paulo, vol. 22, n 65, p. 110/125, out., 2007.

JOSEFO, Flávio. História dos Hebreus: de Abraão à queda de Jerusalém - Obra Completa. 11 ${ }^{\mathrm{a}}$ ed. Rio de Janeiro: CPAD, 2007. 
MOMIGLIANO, Arnaldo. A note on Max Weber's definition of judaism as a pariah-religion. History and Theory, vol. 19, $\mathrm{n}^{\mathrm{o}} 3$, p. 313/318, out., 1980.

MONLOUBOU, Louis e DU BUIT, F. M. Dicionário bíblico universal. Petrópolis, RJ: Vozes; Aparecida, SP: Editora Santuário, 1996.

O Antigo Testamento. A Bíblia de Jerusalém. São Paulo: Edições Paulinas, 2011.

ROMER, Thomas. A chamada História Deuteronomista: introdução sociológica, histórica e literária. Petrópolis, RJ: Vozes, 2008.

SAND, Shlomo. A invenção do povo judeu: da Bíblia ao sionismo. São Paulo: Benvirá, 2011.

SCHLUCHTER, Wolfgang. Ancient Judaism. In. SCHLUCHTER, Wolfgang. Rationalism, religion and domination: a weberian perspective. Oxford: University of California Press, 1989, p. 163/204.

SCHOKEL, Luis Alonso. Dicionário bíblico hebraico-português. Tradução Ivo Storniolo, José Bortolini. São Paulo: Paulus, 1997.

SELL, Carlos Eduardo. Max Weber e a racionalização da vida. Petrópolis, RJ: Vozes, 2013.

WEBER, Max. Ensayos sobre sociología de la religión. Vol. 3, Madrid: Taurus Humanidades, 1987-88. Relações Comunitárias Étnicas. In. WEBER, Max. Economia e sociedade. Vol. I. Brasília: UnB, 1991, p. 267/277.

RECEBIDO EM: 20/12/2015 APROVADO EM: 18/03/2016 